\title{
The effect of osmocote fertilizers on growth and nutrient status of Carex buchananii Berggr.
}

\author{
Monika Henschke ${ }^{1 *}$, Ewelina Wojciechowska ${ }^{2}$, Agnieszka Błaszyk ${ }^{1}$, Katarzyna Araszkiewicz ${ }^{1}$ \\ 'Department of Ornamental Plants, Poznań University of Life Sciences, Dąbrowskiego 159, 60-594 Poznań, Poland \\ ${ }^{2}$ Department of Plant Nutrition, Poznań University of Life Sciences, Zgorzelecka 4, 60-199 Poznań, Poland
}

\begin{abstract}
An experiment on the effect of Osmocote fertilizers on growth and nutrient status of Carex buchananii was conducted in the years 2008-2009. Carex buchananii is a dense-tufted sedge growing up to $60 \mathrm{~cm}$ in height, with very narrow, stiff, red, copper and olive colored leaves throughout the season. Plants were grown in a greenhouse in pots with peat substrate for 18 weeks. The differentiating factors included the type of fertilizer, i.e. Exact Standard 16:11:11 and Osmocote Exact High Start 11:11:19, and fertilizer application rates of 2 and $4 \mathrm{~g} \mathrm{dm}^{-3}$, the phase of growth, i.e. 1 to 9 weeks and 9 to 18 weeks of culture. The greatest increment in the tuft circumference of C. buchananii was recorded in the first 9 weeks of culture, while that of the fresh weight of aboveground parts - in the period from 9 to 18 weeks. The application of Osmocote Exact High Start at $4 \mathrm{~g} \mathrm{dm}^{-3}$ in the culture of $C$. buchananii resulted in the production of the desired quality of the plants with a greater tuft circumference and shorter leaves. It was shown that best quality plants contained in their aboveground parts the following amounts of macronutrients and sodium $\left(\mathrm{g} \mathrm{kg}^{-1}\right)$ : $\mathrm{N}-18.9, \mathrm{P}-3.5, \mathrm{~K}-37.2, \mathrm{Ca}-5.8, \mathrm{Mg}-3.0$, and $\mathrm{Na}-0.3$.
\end{abstract}

Keywords: slow-release fertilizers; leaf length; fresh weight; nitrogen; potassium; Carex buchananii

\section{Introduction}

The genus Carex belongs to the family Cyperaceae and comprises approx. 1500-2000 species. Representatives of this genus are found mainly in the temperate and cool climate zones, they grow in diverse habitats and thus greatly vary in terms of their cultivation requirements [1]. According to Bryson and Carter [2], as many as 53\% of different sedge species are used in horticulture. Carex buchananii is a dense-tufted sedge growing up to $60 \mathrm{~cm}$ in height, with very narrow, stiff, curved leaves, occasionally twisted at the tips, red, copper and olive colored throughout the season. It grows in the wild in New Zealand in lowlands and in montane forest understories, coastal scrubs, and along streams [1,3].

Sedges, similarly as grasses, are being used increasingly often as ornamental plants in green areas [4,5]. Carex buchananii is planted in flower beds and parterres. Due to the attractive leaf color, it may also be used in hanging baskets for balconies and terraces. As young plants may be easily propagated from seed, this sedge may become an attractive addition to the range of balcony plants [6-8]. Since this species is at present being introduced to horticultural production, cultivation recommendations need to be developed

*Corresponding author. Email: mohen@up.poznan.pl

Handling Editor: Elżbieta Weryszko-Chmielewska for this sedge. Studies conducted to date concerned the effect of growth regulators on height and tillering of Carex buchananii [9]. Studies on the growth of sedges under varied mineral fertilization conditions have been conducted mainly on fodder species in their natural localities, particularly in wetlands [10-12]. To date, no fertilization recommendations have been developed for Carex buchananii.

Fertilization is an important cultivation measure in horticultural production. In basic fertilization, slow-release fertilizers, particularly Osmocote, are used in container culture [13-15]. Depending on the requirements of individual species and cultivars, different types and various application rates of this fertilizer may be used.

The aim of this study was to determine the intensity of growth of Carex buchananii Berggr. grown in containers under the influence of two types of Osmocote fertilizers applied at different rates.

\section{Material and methods}

The effect of Osmocote fertilizers on growth and nutrient status of Carex buchananii Berggr. was investigated in greenhouse experiments conducted in the years 2008 and 2009. The experimental factors included the type of fertilizer (Osmocote Exact Standard 16:11:11 and Osmocote Exact High Start 11:11:19 - factor A), fertilizer application rate 
(2 $\mathrm{g}$ and $4 \mathrm{~g}$ per $1 \mathrm{dm}^{3}-$ factor B), and week of culture (9 and 18 - factor $\mathrm{C}$ ). Each of the eight combinations in the first 9 weeks of culture comprised 5 replications, of 5 pots with plants each, while in the successive 9 weeks of culture there were 4 replications with 5 pots with plants. The results were subjected to analysis of variance for a three-factor experiment separately for each year, while to verify specific hypotheses the Newman-Keuls test was applied at a significance level of $\alpha=0.05$.

Plant material comprised seedlings of Carex buchananii produced by Syngenta Sp. z o.o, in trays with 250 pots. In one tray pot there were 7 seedlings with a mean leaf length of $10 \mathrm{~cm}$ in 2008 and 6 seedlings with a mean leaf length of $8.5 \mathrm{~cm}$ in 2009. Both in 2008 and 2009, on May 20, seedlings were transplanted directly from the trays to $0.5 \mathrm{dm}^{3}$ pots. The plants were grown for 9 weeks and next on July 20 they were transplanted to $1.0 \mathrm{dm}^{3}$ pots and grown for the next 9 weeks until September 20. Culture lasted for 18 weeks. The substrate used in the culture was TS2 peat substrate for perennial plants (Klasmann). This substrate with a $\mathrm{pH}$ of 5.8 $\left(\mathrm{H}_{2} \mathrm{O}\right)$ contained peat of the $0-25 \mathrm{~mm}$ fraction, $40 \mathrm{~g} \mathrm{dm}^{-3}$ of expanded clay pellets by R.H.P., and $1.5 \mathrm{~g} \mathrm{dm}^{-3}$ of PG Mix compound fertilizer (14:16:18). Plants were grown using two Osmocote fertilizers with a 3- to 4-month nutrient release time, i.e. Osmocote Exact Standard 16:11:11 with nitrogen as the main nutrient and Osmocote Exact High Start 11:11:19 with potassium as the main nutrient. Each fertilizer was applied at 2 and $4 \mathrm{~g} \mathrm{dm}^{-3}$. Plants were also top-dressed; during stage I it was with a $0.5 \%$ solution $\left(50 \mathrm{~cm}^{3}\right.$ per pot) and in stage II - with a $0.1 \%$ solution $\left(100 \mathrm{~cm}^{3}\right.$ per pot). For plants grown using Osmocote Exact Standard, top-dressing with Kristalon 20:5:10 was applied, while plants fertilized with Osmocote Exact High Start were top-dressed with Peters Professional Special 15:11:29. Top-dressing was performed five times at weekly intervals starting in each stage from the fourth week of culture. The amounts of nutrients supplied in the individual stages of culture are given in Tab. 1 .

Plants were measured in weeks 9 and 18 of culture in 2008 and 2009. Leaf length $(\mathrm{cm})$ was determined on three fully developed leaves formed on randomly selected shoots, tuft circumference $(\mathrm{cm})$ was measured at the plant base, immediately above the substrate level, while fresh weight of aboveground parts (g) was determined on material cut immediately above the substrate surface in five randomly selected plants from each combination. In week 18 of culture, random samples of the aboveground parts of plants were collected for analyses of macronutrient and sodium contents. The samples were dried at a temperature of $50^{\circ} \mathrm{C}$, next they were homogenized and after mineralisation the content of $\mathrm{N}$ was determined according to Kjeldahl, $\mathrm{P}$ : by colorimetry with ammonium molybdate, while the contents of $\mathrm{K}$, Ca and $\mathrm{Na}$ by photometry and $\mathrm{Mg}$ by atomic absorption [16].

\section{Results}

The tuft circumference in C. buchananii in the first year of analysis ranged from $10.2 \mathrm{~cm}$ to $12.3 \mathrm{~cm}$ and in the second year - from $4.7 \mathrm{~cm}$ to $9.7 \mathrm{~cm}$, the leaf length ranged from $64.3 \mathrm{~cm}$ to $89.7 \mathrm{~cm}$ and from $57.8 \mathrm{~cm}$ to $93.2 \mathrm{~cm}$, respectively, while the fresh weight of aboveground parts in the first year ranged from $9.6 \mathrm{~g}$ to $28.4 \mathrm{~g}$ and in the second year from $7.1 \mathrm{~g}$ to $28.1 \mathrm{~g}$, respectively (Tab. 2).

The analysis of variance showed that tuft circumference in C. buchananii in the first and second years of analysis was influenced by all the three factors (type of fertilizer, its application rate, and week of culture). A greater tuft circumference was obtained in week 18 of culture after the application of Osmocote Exact High Start at $4 \mathrm{~g} \mathrm{dm}^{-3}$ substrate. In the first year of culture, in the period from week 9 to 18 the tuft circumference increased by as little as $8 \%$, while in the second year of culture by $60 \%$. Irrespective of the week of culture, plants with the largest tuft circumference were obtained following fertilization with Osmocote Exact High Start applied at the higher rate. When analyzing the interactions of all the factors, it was shown that the lower application rate of this fertilizer had a similar effect on this trait as the higher rate of Osmocote Exact Standard between weeks 9 and 18 of culture. The smallest tuft circumference was recorded for plants fertilized with Osmocote Exact Standard at the beginning of culture, irrespective of the applied rate, whereas after week 9 it was found only in plants fertilized with the lower application rates.

Leaf length in C. buchananii depended on all the experimental factors. Leaves longer by approx. $30 \%$ were found in plants in week 18 in comparison to the leaf length in week 9 of culture in both years of analysis. The application of Osmocote Exact High Start (only in the second year of analysis) at the lower rates resulted in the production of longer leaves. Irrespective of the weeks in which measurements were taken or the type of fertilizer, plants to whose substrate the lower fertilizer doses were applied produced longer leaves. When

Tab. 1 The amount of various ingredients provided at different stages of cultivation in each pot in the years 2008 and 2009.

\begin{tabular}{|c|c|c|c|c|c|c|c|c|c|c|}
\hline \multirow[b]{3}{*}{ Fertilizer } & \multirow[b]{3}{*}{$\begin{array}{l}\text { Dose } \\
\left(\mathrm{g} \mathrm{dm}^{-3}\right)\end{array}$} & \multicolumn{9}{|c|}{ Ingredient dose (mg per pot) } \\
\hline & & \multicolumn{3}{|c|}{$\mathbf{N}$} & \multicolumn{3}{|c|}{$\mathbf{P}$} & \multicolumn{3}{|c|}{$\mathbf{K}$} \\
\hline & & Stage I* & $\underset{\mathbf{I I}^{* *}}{\text { Stage }}$ & $\begin{array}{l}\text { Sum } \\
\text { I + II }\end{array}$ & Stage I & Stage II & $\begin{array}{l}\text { Sum } \\
I+\text { II }\end{array}$ & Stage I & Stage II & $\begin{array}{c}\text { Sum } \\
\text { I + II }\end{array}$ \\
\hline \multirow{2}{*}{$\begin{array}{l}\text { Osmocote Exact Standart } \\
\text { 16:11:11 }\end{array}$} & 2 & 290.0 & 365.0 & 655.0 & 104.0 & 112.2 & 216.2 & 213.8 & 244.9 & 458.7 \\
\hline & 4 & 450.0 & 525.0 & 975.0 & 152.4 & 160.6 & 313.0 & 305.1 & 336.2 & 641.3 \\
\hline \multirow{2}{*}{$\begin{array}{l}\text { Osmocote Exact High } \\
\text { Start 11:11:19 }\end{array}$} & 2 & 233.8 & 290.0 & 523.8 & 104.0 & 112.2 & 216.5 & 299.9 & 390.2 & 690.1 \\
\hline & 4 & 343.8 & 400.0 & 743.8 & 152.4 & 160.6 & 313.0 & 457.6 & 547.9 & 1005.5 \\
\hline
\end{tabular}

${ }^{\star} 1$ to 9 weeks of culture. ${ }^{*} 9$ to 18 weeks of culture. 
Tab. 2 Influence of week of cultivation, two types of Osmocote fertilizers used in different dosages on tuft circumference, leaf length and fresh matter of the aboveground parts of C. buchananii in the years 2008 and 2009; the average for eight combinations and the combination of boundary.

\begin{tabular}{|c|c|c|c|c|c|c|c|c|}
\hline \multirow[b]{2}{*}{ Week } & \multirow[b]{2}{*}{ Fertilizer } & \multirow{2}{*}{$\begin{array}{c}\text { Dose } \\
\left(\mathrm{g} \mathrm{dm}^{-3}\right)\end{array}$} & \multicolumn{2}{|c|}{$\begin{array}{l}\text { Tuft circumference } \\
(\mathbf{c m})\end{array}$} & \multicolumn{2}{|c|}{ Leaf length $(\mathrm{cm})$} & \multicolumn{2}{|c|}{ Fresh matter (g) } \\
\hline & & & 2008 & 2009 & 2008 & 2009 & 2008 & 2009 \\
\hline \multirow[t]{4}{*}{9} & Osmocote Exact Standart & 2 & $10.2 \mathrm{a}^{\star}$ & $4.7 \mathrm{a}$ & $67.8 \mathrm{~b}$ & $61.5 \mathrm{ab}$ & $10.6 \mathrm{a}$ & $8.3 \mathrm{a}$ \\
\hline & $16: 11: 11$ & 4 & $10.5 \mathrm{a}$ & $4.9 \mathrm{a}$ & $67.5 \mathrm{~b}$ & $57.8 \mathrm{a}$ & $11.0 \mathrm{a}$ & $7.1 \mathrm{a}$ \\
\hline & Osmocote Exact High Start & 2 & $11.0 \mathrm{~b}$ & $5.8 \mathrm{~b}$ & $68.3 \mathrm{~b}$ & $63.8 \mathrm{~b}$ & $9.6 \mathrm{a}$ & $7.4 \mathrm{a}$ \\
\hline & $11: 11: 19$ & 4 & $10.9 \mathrm{~b}$ & $6.2 \mathrm{~b}$ & $64.3 \mathrm{a}$ & $62.9 \mathrm{~b}$ & $10.2 \mathrm{a}$ & $8.3 \mathrm{a}$ \\
\hline \multirow[t]{8}{*}{18} & Osmocote Exact Standart & 2 & $11.1 \mathrm{~b}$ & $7.6 \mathrm{c}$ & $89.0 \mathrm{~d}$ & $87.8 \mathrm{~d}$ & $28.4 \mathrm{~b}$ & $24.4 \mathrm{~b}$ \\
\hline & $16: 11: 11$ & 4 & $11.5 \mathrm{c}$ & $8.0 \mathrm{c}$ & $85.7 \mathrm{c}$ & $80.5 \mathrm{c}$ & $25.9 \mathrm{~b}$ & $23.9 \mathrm{~b}$ \\
\hline & Osmocote Exact High Start & 2 & $11.6 \mathrm{c}$ & $8.9 \mathrm{~d}$ & $89.7 \mathrm{~d}$ & $93.2 \mathrm{e}$ & $28.2 \mathrm{~b}$ & $27.8 \mathrm{c}$ \\
\hline & $11: 11: 19$ & 4 & $12.3 \mathrm{~d}$ & $9.7 \mathrm{e}$ & $87.1 \mathrm{c}$ & $91.4 \mathrm{de}$ & $27.3 \mathrm{~b}$ & $28.1 \mathrm{c}$ \\
\hline & Osmocote Exact Standart & 2 & $10.7 \mathrm{a}$ & $6.1 \mathrm{a}$ & $78.4 \mathrm{~b}$ & $74.6 \mathrm{~b}$ & $19.5 \mathrm{a}$ & $16.3 \mathrm{ab}$ \\
\hline & $16: 11: 11$ & 4 & $11.0 \mathrm{~b}$ & $6.5 \mathrm{~b}$ & $76.6 \mathrm{a}$ & $69.1 \mathrm{a}$ & $18.4 \mathrm{a}$ & $15.5 \mathrm{a}$ \\
\hline & Osmocote Exact High Start & 2 & $11.3 \mathrm{~b}$ & $7.3 c$ & $79.0 \mathrm{~b}$ & $78.5 \mathrm{c}$ & $18.9 \mathrm{a}$ & $17.6 \mathrm{~b}$ \\
\hline & $11: 11: 19$ & 4 & $11.9 \mathrm{c}$ & $7.9 \mathrm{~d}$ & $75.7 \mathrm{a}$ & $77.1 \mathrm{bc}$ & $18.7 \mathrm{a}$ & $18.2 \mathrm{~b}$ \\
\hline 9 & & & $10.7 \mathrm{a}$ & $5.4 \mathrm{a}$ & $67.0 \mathrm{a}$ & $61.5 \mathrm{a}$ & $10.3 \mathrm{a}$ & $7.8 \mathrm{a}$ \\
\hline \multirow[t]{5}{*}{18} & & & $11.6 \mathrm{~b}$ & $8.5 \mathrm{~b}$ & $87.9 \mathrm{~b}$ & $88.2 \mathrm{~b}$ & $27.4 \mathrm{~b}$ & $26.0 \mathrm{~b}$ \\
\hline & $\begin{array}{l}\text { Osmocote Exact Standart } \\
16: 11: 11\end{array}$ & & $10.8 \mathrm{a}$ & $6.3 \mathrm{a}$ & $77.5 \mathrm{a}$ & $71.9 \mathrm{a}$ & $19.0 \mathrm{a}$ & $15.9 \mathrm{a}$ \\
\hline & $\begin{array}{l}\text { Osmocote Exact High Start } \\
11: 11: 19\end{array}$ & & $11.4 \mathrm{~b}$ & $7.6 \mathrm{~b}$ & $77.4 \mathrm{a}$ & $77.8 \mathrm{~b}$ & $18.8 \mathrm{a}$ & $17.9 \mathrm{~b}$ \\
\hline & & 2 & $11.0 \mathrm{a}$ & $6.7 \mathrm{a}$ & $78.7 \mathrm{~b}$ & $76.6 \mathrm{~b}$ & $19.2 \mathrm{a}$ & $17.0 \mathrm{a}$ \\
\hline & & 4 & $11.3 \mathrm{~b}$ & $7.2 \mathrm{~b}$ & $76.1 \mathrm{a}$ & $73.1 \mathrm{a}$ & $18.6 \mathrm{a}$ & $16.9 \mathrm{a}$ \\
\hline
\end{tabular}

${ }^{*}$ Means marked with at least one same letter in the highlighted portion of the column are not significantly different at a level of $\alpha=0.05$.

analyzing the interactions of all the three factors in the first year of analysis, the longest leaves were found in plants in week 18 of culture after the application of Osmocote Exact Standard and Osmocote Exact High Start at the lower rates. In turn, the shortest leaves were recorded in plants in week 9 of culture, fertilized with Osmocote Exact High Start at the higher application rate. Similarly, in the second year of analysis the longest leaves were produced by plants in week 18 of culture following the application of Osmocote Exact High Start at the lower rate, but they did not differ significantly from the length of leaves in plants grown in the substrate with the higher doses of this fertilizer. In the second year of analysis, the shortest leaves were found in plants in week 9 of culture in the substrate supplemented with Osmocote Exact Standard at the higher application rate, although the leaf length did not differ significantly from that of plants grown in the substrate with the lower application rate of this fertilizer.

The results of the analysis of variance indicate a significant effect of the date of measurement on fresh weight of C. buchananii in both years of analysis. In turn, the type of the applied fertilizer significantly differentiated the results only in the second year of analysis and the fertilizer application rate had no significant effect in both years of analysis. Plants with a higher fresh weight were obtained in week 18 of culture. In 2009 Osmocote Exact High Start had a beneficial effect on this trait. Between weeks 9 and 18 of culture, the fresh weight of plants increased approx. three times. In 2009, when analyzing the interactions of all the three factors, the type of fertilizer was shown to influence this trait only between weeks 9 and 18 of culture. After 18 weeks of culture, the highest weight was recorded for plants fertilized with Osmocote Exact High Start. The application rates of both fertilizers did not significantly differentiate the results for both types of fertilizer. Since the effect of the type of fertilizer and its application rate on this trait was demonstrated only in one of the two years of analysis, thus these results should be treated with caution. They indicate the need to conduct further studies in this respect.

After 18 weeks of culture, the nitrogen content in the aboveground parts of $C$. buchananii ranged from 1.75 to $2.00 \%$, with higher values recorded after fertilization with Osmocote Exact Standard and after the application of the higher fertilizer doses (Tab. 3). The use of Osmocote Exact Standard also resulted in a higher Ca content in plants. In turn, the $\mathrm{K}$ content ranged from 3.42 to $3.94 \%$ and it was higher after the application of Osmocote Exact High Start and after the application of the lower rates of fertilizers. The contents of $\mathrm{P}$ and $\mathrm{Na}$ in the aboveground parts of C. buchananii were uniform in all the treatments. Since optimal quality plants were produced after fertilization with Osmocote Exact 
Tab. 3 The content of macronutrients and sodium in the dry matter of leaves after 18 weeks of cultivation depending on fertilization of plants (average for 2008, 2009).

\begin{tabular}{lccccccc} 
& Dose & $\mathbf{N}$ & $\mathbf{P}$ & $\mathbf{K}$ & $\mathbf{C a}$ & $\mathbf{M g}$ & $\mathbf{N a}$ \\
\cline { 3 - 8 } Fertilizer & $\left(\mathbf{g ~ d m}^{-3}\right)$ & \multicolumn{7}{c}{$\left(\mathbf{g ~ k g}^{-1}\right)$} \\
\hline Osmocote Exact Standart 16:11:11 & 2 & 19.5 & 3.5 & 36.1 & 7.6 & 3.2 & 0.3 \\
& 4 & 20.0 & 3.7 & 34.2 & 9.2 & 3.3 & 0.3 \\
Osmocote Exact High Start 11:11:19 & 2 & 17.5 & 3.4 & 39.4 & 5.8 & 2.9 & 0.4 \\
& 4 & 18.9 & 3.5 & 37.2 & 5.8 & 3.0 & 0.3 \\
\hline
\end{tabular}

High Start applied at the higher rate, the following contents of nutrients in the aboveground parts of C. buchananii may be considered adequate $\left(\mathrm{g} \mathrm{kg}^{-1}\right): \mathrm{N}-18.9, \mathrm{P}-3.5, \mathrm{~K}-37.2$, $\mathrm{Ca}-5.8, \mathrm{Mg}-3.0$, and $\mathrm{Na}-0.3$.

\section{Discussion}

In this experiment, weeks of culture were shown to have a significant effect on the analyzed traits of $C$. buchananii. In the first and second year of culture, the tuft circumference, leaf length, and fresh weight of aboveground parts were greater after 18 weeks than after 9 weeks of culture. An intensive increase in C. lasiocarpa biomass during the summer period in natural localities in China was also recorded by Yang et al. [17]. In this experiment, the growth between weeks 9 and 18 of culture also occurred in the second half of July and in August. Moreover, Newman et al. [18] found that the release of nutrients from slow-release fertilizers is highly unstable in the first 15 weeks. During this time, EC of the substrate may be from 3 to 5 times greater than in the later period. What is more, for the first 5 weeks Osmocote fertilizers release nitrogen mainly as $\mathrm{NH}_{4}{ }^{+}$. This could have caused the poorer growth of plants during the first 9 weeks of culture.

The type of fertilizer applied had a significant effect on tuft circumference in both years of analysis, and also on leaf length and fresh weight of aboveground parts, but only in the second year of analysis. Osmocote Exact High Start, i.e. a fertilizer with potassium as the main nutrient, was found to have a more beneficial effect on the qualitative traits of plants. Since the aboveground parts of C. buchananii are composed of densely arranged, small leaf rosettes, it is very difficult to determine their number. The number of rosettes indicates the tuft circumference measured immediately above the substrate surface. The effect of nitrogen-potassium fertilization on growth of Coreopsis grandiflora 'Early Sunrise' and Delphinium grandiflorum 'Blauer Spiegel' was also investigated by Kozik and Szymankiewicz [19]. These authors showed that different application rates of potassium had no effect on plant growth, while after the application of higher doses of nitrogen plants produced more shoots and a higher fresh weight of aboveground parts. In the culture of Clematis from the group Jackmanii 'John Paul II' Bosiacki [20] obtained plants with a greater fresh weight when applying Osmocote Exact Standard in comparison to Osmocote Exact High Start. Opposite results in this experiment indicate specific fertilization requirements of $C$. buchananii.
The dose of fertilizers applied had an effect on tuft circumference and leaf length in C. buchananii. Plants with a greater tuft circumference were produced using the higher application rates $\left(4 \mathrm{~g} \mathrm{dm}^{-3}\right)$, while plants with longer leaves were obtained using the lower fertilizer doses $\left(2 \mathrm{~g} \mathrm{dm}^{-3}\right)$. The effect of the application rate of another slow-release fertilizer, Hydrocote type 40, on tillering of Heuchera sanguinea was investigated by Czuchaj and Szczepaniak [21]. After the application of higher doses $\left(2.5\right.$ and $\left.3.5 \mathrm{~g} \mathrm{dm}^{-3}\right)$, plants produced more shoots. However, slightly different results were reported by Czuchaj et al. [22], as in the culture of Helleborus argutifolius the application rate of Osmocote Plus had no effect on the number of leaves, in contrast to Hydrocote, whose higher dose stimulated the production of a greater number of leaves. Similarly, Bosiacki [20] obtained Clematis from the group Jackmanii cv. 'John Paul II' with the highest fresh weight after the application of Osmocote Exact Standard at a dose below $6 \mathrm{~g} \mathrm{dm}^{-3}$ compared to Osmocote Exact High Start at $8 \mathrm{~g} \mathrm{dm}^{-3}$. In turn, Kozik and Wechta [23] and Kozik et al. [24] showed that after the application of the higher dose of Osmocote Plus in the culture of Coreopsis grandiflora cv. 'Early Sunrise' plants produced a higher number of shoots and a greater fresh weight. However, Aerts and Calowe [25] showed that increased nitrogen fertilization in culture of four sedge species led to reduced vigor of shoots.

The higher contents of $\mathrm{N}$ in the aboveground parts of $C$. buchananii were influenced by the type of fertilizer and its application rate. Plants with higher contents of this nutrient were produced after the application of the higher fertilizer doses, particularly Osmocote Exact Standard. In turn, the highest $\mathrm{K}$ content in plants was recorded after the application of Osmocote Exact High Start, but at the lower doses. These results may indicate a relationship between the contents of $\mathrm{N}$ and $\mathrm{K}$ in the leaves of $C$. buchananii. In another experiment, the application of Osmocote Plus at the higher rates in the culture of Delphinium grandiflorum 'Blauer Spiegel' also resulted in a higher $\mathrm{N}$ content in the leaves, while at the highest dose the $\mathrm{K}$ content was lower [26]. Different fertilization levels in this experiment had no marked effect on the contents of phosphorus and sodium in the aboveground parts of C. buchananii. In turn, in a study of Schroeter-Zakrzewska and Kleiber [27] significantly better phosphorus nutrition of marguerite daisy was observed after the application of Osmocote Exact Standard in comparison to Osmocote Exact High Start. Moreover, the authors showed a lack of significant differences in the contents of other macro- and micronutrients in plants. 


\section{Conclusions}

The greatest increment in tuft circumference in Carex buchananii was observed in the first 9 weeks of culture, while that of the fresh weight of aboveground parts was found between weeks 9 and 18 .

The application of Osmocote Exact High Start in the culture of $C$. buchananii resulted in the production of plants with a greater tuft circumference than after the application of Osmocote Exact Standard.

\section{Acknowledgments}

This work was financially supported by the Ministry of Science and Higher Education as part of the research to sustain the research potential of the Department of Ornamental Plants at the University of Life Sciences in Poznań. The plant material for research was provided by Syngenta Sp. z o.o.

\section{Authors' contributions}

The following declarations about authors' contributions to the research have been made: concept of the study: $\mathrm{MH}$; field research: $\mathrm{MH}, \mathrm{EW}, \mathrm{AB}$, $\mathrm{KA}$; data analyses: $\mathrm{MH}$, writing of the manuscript: $\mathrm{MH}$, comments on the manuscript: $\mathrm{MH}$

\section{Competing interests}

No competing interests have been declared.

\section{References}

1. Grabowska B, Kubala T. Encyklopedia bylin. Poznań: Zysk I S-ka Wydawnictwo s.j.; 2011.

2. Bryson CT, Carter R. The significance of Cyperaceae as weeds. Monogr Syst Bot Missouri Bot Gard. 2008;108:15-101.

3. Foerster K. Einzug der Gräser und Farne in die Gärten. 7th ed. Radebeul: Neuman Verlag Leipzig; 1988.

4. Dana MN. Ornamental grasses and sedges as new crops. In: Janick J, Whipkey A, editors. Trends in new crops and new uses. Alexandria: ASHS Press, VA; 2002. p. 473-476.

5. Henschke M. Znaczenie traw ozdobnych w terenach zieleni. Ogrodnictwo Ozdobne sektorem gospodarki narodowej. Warszawa: SGGW; 2013. p. 119-123.

6. Armitage AM. Herbaceous perennial plants. A treatise on their identification, culture, and garden attributes. Champaign, IL: Stipes Publishing; 1997. p. 230-234.

7. Pilon P. Perennials solutions. A grower's guide to perennial production Batavia, IL: Ball Publishing; 2006. p. 436-447.

8. Hanke H. Attraktive Ziergräser für den Herbstverkauf. Zierpflanzenbau. 2008;5:27-31.

9. Padhye SR, Groninger JK. Influence of benzyloadenina, trinexapacethyl, or uniconazole applications on height and tillering of six ornamental grasses. Hort Technol. 2009;19(4):737-742.

10. Konings H, Verhoeven JTA, de Grot R. Growth characteristics and seasonal allocation patterns of biomass and nutrients in Carex species growing in floating fens. Plant Soil. 1992;147:183-196. http://dx.doi. org/10.1007/BF00029070

11. Reece PE, Nichols JT, Brummer JE, Engel RK, Eskridge KM. Harvest date and fertilizer effects on native and intercede wetland meadows. J Range Manage. 1994;47(3):178-183. http://dx.doi. org/10.2307/4003012

12. Güsewell S. High nitrogen: phosphorus ratios reduce nutrient retention and second-year growth of wetland sedges. New Phytol. 2005;166:537-550. http://dx.doi.org/10.1111/j.1469-8137.2005.01320.x

13. Szczepaniak S, Kozik E. Wpływ rodzaju i objętości podłoża oraz nawozów o spowolnionym działaniu na wzrost młodych roślin nachyłka wielkokwiatowego. Rocz AR Pozn Ogrod. 2004;360(38):157-161.
The higher fertilizer application rate $\left(4 \mathrm{~g} \mathrm{dm}^{-3}\right)$ resulted in the production of plants with a greater circumference and shorter leaves.

In the culture of C. buchanani, it is recommended to use Osmocote Exact High Start at $4 \mathrm{~g} \mathrm{dm}^{-3}$.

The best quality plants of Carex buchananii contained in their aboveground parts the following contents of macronutrients and sodium $\left(\mathrm{g} \mathrm{kg}^{-1}\right): \mathrm{N}-18.9, \mathrm{P}-3.5, \mathrm{~K}-37.2$, $\mathrm{Ca}-5.8, \mathrm{Mg}-3.0$ and $\mathrm{Na}-0.3$, respectively.

14. Korszun S, Zalewska J. Zastosowanie nawozu Osmocote Exact Lo-Start w uprawie jałowca skalnego (Juniperus scopulorum Sarg.) odmiany 'Blue Arrow' w pojemnikach. Folia Univ Agric Stetin Agricult. 2004;236(94):81-86

15. Shaviv A. Controlled release fertilizers. In: IFA international workshop on enhanced-efficiency fertilizers, Frankfurt, Germany. Frankfurt: International Fertilizer Industry Association; 2006. p. 1-13.

16. Nowosielski O. Metody oznaczania potrzeb nawożenia. 2nd ed. Warszawa: PWRiL; 1974

17. Yang W, Jing-Shuang L, Jing-xin D, Guang-Ying Z. Seasonal characteristics of Carex lasiocarpa biomass and nutrient accumulation in the typical wetland of Sanjiang Plain, China. J For Res. 2010;21(3): 389-393. http://dx.doi.org/10.1007/s11676-010-0087-y

18. Newman JP, Albano JP, Merhaut DJ, Blythe EK. Nutrient release from controlled-release fertilizers in a neutral-pH substrate in an outdoor environment: I. Leachate electrical conductivity, $\mathrm{pH}$, and Nitrogen, phosphorus, and potassium concentrations. Hort Sci. 2006;41(7):1674-1682

19. Kozik E, Szymankiewicz M. Wpływ nawożenia azotowo-potasowego na wzrost i kwitnienie nachyłka wielkokwiatowego (Coreopsis grandiflora Hogg.) i ostróżki wielkokwiatowej (Delphinium grandiflorum L.). Rocz AR Pozn Ogrod. 2004;356(37):123-128.

20. Bosiacki M. Effect of type of Osmocote fertilizers on the growth and yielding of Clematis from Jackmanii group 'John Paul II' cultivar. Acta Sci Pol Hortorum Cultus. 2008;7(1):63-71.

21. Czuchaj P, Szczepaniak S. Wpływ rodzaju i objętości podłoża oraz dawki nawozu Hydrocote typ 40 na wzrost młodych roślin żurawki krwistej (Heuchera sanguinea Engelm.). Zesz Probl Post Nauk Rol. 2006;510:113-118

22. Czuchaj P, Henschke M, Szczepaniak S. Wzrost i kwitnienie ciemiernika korsykańskiego (Helleborus argutifolius Viv.) w zależności od dawki i rodzaju nawozu wolnodziałającego. Zesz Probl Post Nauk Rol. 2010;551:31-37

23. Kozik E, Wechta M. Wpływ nawozów Osmocote Plus na wzrost kwitnienie nachyłka wielkokwiatowego (Coreopsis grandiflora Hogg.) 'Early Sunrise'. Folia Hortic. 2003;2:43-45.

24. Kozik E, Henschke M, Loch N. Growth and flowering of Coreopsis grandiflora Hogg. under the influence of Osmocote Plus fertilizers. Rocz AR Pozn Ogrod. 2004;356(37):117-122.

25. Aerts $\mathrm{R}$, Calowe $\mathrm{H}$. Interspecific and intraspecific differences in shoot and Lear lifespan of four Carex species which differ in maximum dry matter production. Oecologia. 1995;102:467-477. http://dx.doi. org/10.1007/BF00341359

26. Kozik E, Henschke M. Wstępna ocean wzrostu i kwitnienia ostróżki wielkokwiatowej (Delphinium grandiflorum L.) w uprawie doniczkowej w zależności od nawożenia Osmocote. Rocz AR Pozn Ogrod. 2004;360(38):111-117.

27. Schroeter-Zakrzewska A, Kleiber T. Application of slow release fertilizers in growing marguerite Daisy (Argyranthemum frutescens) Molimba group. Ecol Chem Eng A. 2012;19(12):1471-1484. 


\section{Wpływ nawozów typu Osmocote na wzrost i stan odżywienia Carex buchananii Berggr.}

\section{Streszczenie}

Doświadczenie nad wpływem nawozów typu Osmocote na wzrost i stan odżywienia Carex buchananii przeprowadzono w latach 2008-2009. Carex buchananii to turzyca gęstokępkowa, która dorasta do $60 \mathrm{~cm}$ wysokości. Liście ma bardzo wąskie o barwie czerwonej, miedzianej i oliwkowej przez cały sezon. Rośliny uprawiano w szklarni w doniczkach w substracie torfowym przez 18 tygodni. Czynnikami różnicującymi wyniki były: typ nawozu Exact Standard 16:11:11 i Osmocote Exact High Start 11:11:19 oraz dawki nawozów 2 i $4 \mathrm{~g} \mathrm{dm}^{-3}$; etap wzrostu od 1 do 9 tygodnia i od 9 do 18 tygodnia uprawy. Największy przyrost obwodu kęp Carex buchananii nastąpił w pierwszych 9 tygodniach uprawy, a świeżej masy części nadziemnej pomiędzy 9 i 18 tygodniem. Zastosowanie Osmocote Exact High Start w dawce $4 \mathrm{~g} \mathrm{dm}^{-3}$ wpłynęło na uzyskanie pożądanej jakości roślin, o większym obwodzie kęp i krótszych liściach. Wykazano, że najlepszej jakości rośliny zawierały w części nadziemnej następujące zawartości makroskładników i sodu $\left(\mathrm{g} \mathrm{kg}^{-1}\right)$ : $\mathrm{N}-18.9, \mathrm{P}-3.5, \mathrm{~K}-37.2$, $\mathrm{Ca}-5.8, \mathrm{Mg}-3.0, \mathrm{Na}-0.3$. 